\title{
GENERAL DISCUSSION, SUMMARY AND RESOLUTIONS
}

